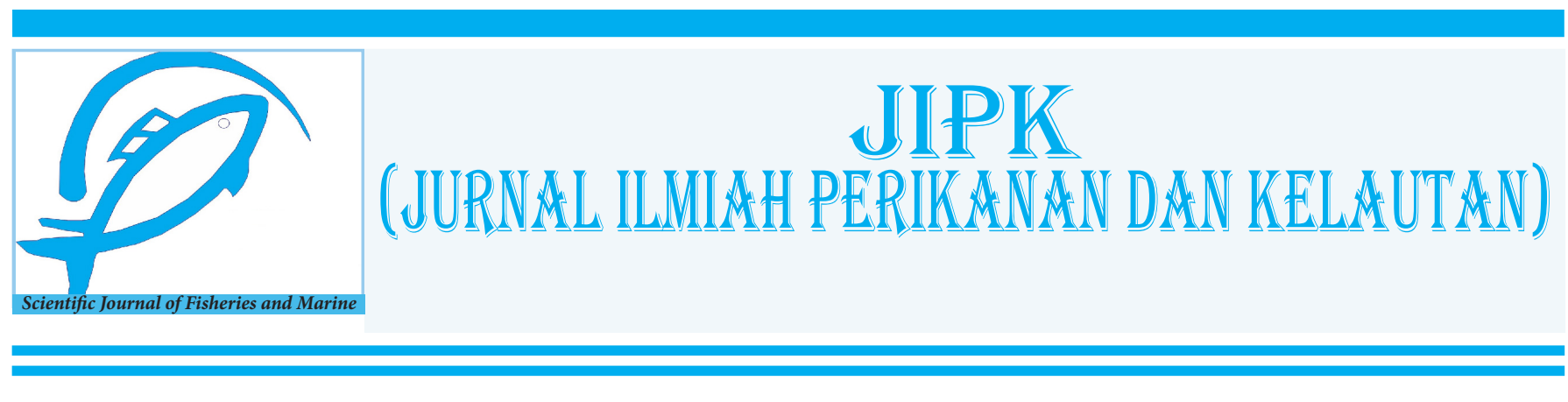

Research Article

\title{
Carbon Sink Estimation of Mangrove Vegetation Using Remote Sensing in Segara Anakan, Cilacap
}

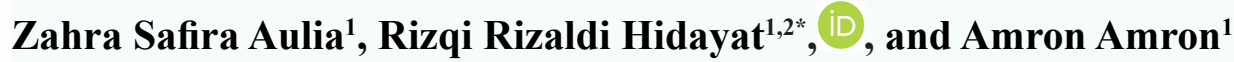

${ }^{1}$ Marine Science Department, Fisheries and Marine Science Faculty, Jenderal Soedirman University, Purwokerto, 53122. Indonesia

${ }^{2}$ Centre for Maritime Bioscience, Institute for Research and Community Services, Jenderal Soedirman University, Purwokerto, 53122. Indonesia

\section{OPEN ACCESS}

\section{ARTICLE INFO}

Received: November 30, 2021

Accepted: February 15, 2022

Published: February 18, 2022

*) Corresponding author:

E-mail: rizqi.rizaldi@unsoed.ac.id

Keywords:

Global Warming

Mangrove

Carbon Sink

Remote Sensing

This is an open access article under the CC BY-NC-SA license (https://creativecommons.org/ licenses/by-nc-sa/4.0/)

\section{Abstract}

Worldwide global warming occurs because of increasing carbon dioxide $\left(\mathrm{CO}_{2}\right)$ in the atmosphere. Segara Anakan, the largest mangrove forest in Java Island, has the highest potential as a carbon sink in the tropics. This study aimed to quantify the area and density of mangrove forests in Segara Anakan and to estimate their potentials as carbon sink based on Sentinel-2A imagery. In this study, data from Sentinel 2A satellite imagery was processed and validated with field survey results. The results showed that Segara Anakan had mangrove forests covering an area of 5,481.64 ha in 2019 with the sparse density covered 706.92 ha, medium density covered of 2,526.80 ha, and high density covered 2,848.60 ha. The results of mangrove density were validated using Table Confusion Matrix and using correlation coefficient value (r) by comparing field measurement and Normalized Difference Vegetation Index (NDVI) algorithm. The accuracy for mangrove density was $86.92 \%$ with r-value 0.85 . Mangrove in Segara Anakan has the ability to absorb 8.56 Mega gram of carbon per hectare. Segara Anakan mangroves have the potential to absorb high level of carbon, so we should maintain their sustainability.

Cite this as: Aulia, Z. S., Hidayat, R. R., \& Amron, A. (2022). Carbon Sink Estimation of Mangrove Vegetation Using Remote Sensing in Segara Anakan, Cilacap. Jurnal Ilmiah Perikanan dan Kelautan, 14(1):130-141. http://doi.org/10.20473/jipk. v14i1.31789 


\section{Introduction}

Worldwide global warming is one of the most natural issues encountered every nations in the world, worldwide global warming occurs because of increasing carbon dioxide $\left(\mathrm{CO}_{2}\right)$ in the atmosphere (Bindu et al., 2020). The increasing $\mathrm{CO}_{2}$ is followed by the decreasing area of forests on earth which functions as a $\mathrm{CO}_{2}$ sink. Forests have an important role in reducing $\mathrm{CO}_{2}$ in the air through the use of $\mathrm{CO}_{2}$ in the photosynthesis process. The amount of carbon in a tree can describe how much the tree can tie up $\mathrm{CO}_{2}$ from the air (Utomo et al., 2021). Nuraini et al. (2021) reported that some of the carbon will turn into energy used for photosynthesis and part of it will enter the plant structure and become part of the plant stored in stems, roots, twigs, and leaves.

Mangrove forests per hectare can save three to four times more carbon than other tropical forests around the world (Donato et al., 2011). Indonesia is a country that has the largest mangrove forest in the world so Indonesia has an important role in minimizing the impact of Global Warming (Murdiyarso et al., 2015). The impact of Global Warming can be minimized by cooperation between countries through carbon trading. Carbon trading means that tropical forested countries must protect their forests to absorb $\mathrm{CO}_{2}$ and industrialized countries must pay to tropical forest countries. However, the area of mangrove forests continues to decline, as happened in Segara Anakan, Cilacap. The extent and density of mangroves in 2003-2015 continued to decline in area and density due to a large number of land-use conversions from one land cover to another (Utami et al., 2016).

Remote sensing has been used in marine science and its applications are growing. Remote sensing can be used as a method of estimating the potential of mangroves as carbon sink because they are superior in terms of costs, wide-area coverage when compared to the field surveys method. By using remote sensing, mapping changes in the area and estimating the potential of mangroves as carbon sink can be determined in time series (Bindu et al., 2020; Patil et al., 2015; Wicaksono et al., 2016). Measurement of mangrove carbon stock estimation using remote sensing is expected to reduce the destructive tendency of field survey method (Muhsoni et al., 2018). Estimation of mangrove carbon stock begins with mapping the classification of mangrove land cover. Land cover classification is processed using supervised classification method with a sampling procedure of multiple pixels for each one class/object (Siddiq et al., 2020). Wang et al. (2018) demonstrated the potential of Sentinel - 2A satellite imagery as a valu- able data source for mapping different scales of mangrove features. Patil et al. (2015) reported that use of remote sensing to estimate biomass and mangrove carbon stock produces an accuracy of $96.4 \%$. Nguyen et al. (2020) measuring the estimated mangrove density using the NDVI algorithm and producing an accuracy value of $85.5 \%$ and estimated mangrove carbon stock using remote sensing and obtained an accuracy of $61.1 \%$. Research conducted by Askar et al. (2018) shows that the use of NDVI to estimated mangrove density obtained an $R^{2}$ value of 0.79 and carbon stock estimates with $R^{2}$ value of 0.81 . According to Vafaei et al. (2018) Sentinel $2 \mathrm{~A}$ satellite imagery has the ability to estimate mangrove carbon stock mapping with a better accuracy than ALOS-2 PALSAR-2. According to Sani and Hashim (2018) the high and low ability of mangroves to absorb carbon is caused by variation in geographic location, the higher the diversity and density of mangrove forests, the higher their ability to absorb carbon. The mangrove ecosystems usually store more carbon than the dryland tropical forest ecosystems (Parida and Kumari, 2020).

However, all previous study were focused on measuring carbon stocks and biomass in mangrove forests. To the best of our knowledge, only a few studies have been conducted on the ability of mangroves to absorb carbon dioxide. The measurement of the estimated carbon absorption in Segara Anakan Cilacap using remote sensing was also never studied before, despite the fact that Segara Anakan Cilacap is a location that has high mangrove diversity. This study aims to calculate the extent and density of mangroves in Segara Anakan based on Sentinel-2A satellite image data and to determine the potential of mangrove forests in the Segara Anakan area as carbon sink based on the area and density obtained from Sentinel-2A satellite image data.

\section{Materials and Methods}

\subsection{Study Area}

Research was conducted at Segara Anakan Lagoon, Cilacap, Central Java. The Segara Anakan are located between $7^{\circ} 35^{\prime}-7^{\circ} 50^{\prime}$ south and $108^{\circ} 45^{\prime}$ $109^{\circ} 03^{\prime}$ east. This lagoon gets direct protection from the island of Nusa Kambangan from the Indian Ocean waves. According to Ismail et al. (2018) Segara Anakan Cilacap received sedimentary deposits from various anthropogenic activities, especially the Citanduy, Cibeureum, Cikonde, Donan, and Sapuregel rivers. Lagoon are dominated with mud substrates.

\subsection{Material and Method}

The tools used in this research are satellite 
image processing software, mangrove canopy density processing software, global positioning system (GPS - Garmin), measuring rope, transects and camera. The material used in this study are primary and secondary data. Primary data used in this study are mangrove trunk diameter and canopy density. Secondary data used in this study is Sentinel 2A satellite imagery recorded in August 2019.

This study includes satellite pre-survey image processing, field data collection, and post-survey data calculation. The results of image data processing are used to determine the extent and density of mangroves and to determine the description of the research location. Data collection in the field was carried out to collect data on the diameter of mangrove trees to determine the value of biomass that will be used to find the value of carbon sink and canopy density at the research location. The technique used during the field survey was purposive sampling. This sampling technique was chosen to obtain sample representation at the research location by considering the safety and ease of access to sampling.

\subsubsection{Pre-survey image processing}

Pre-survey image processing is carried out to determine the location of the sampling point. These stages include radiometric correction, masking, and calculate the area and density of mangroves. Radiometric correction aims to improve image quality by reducing the interference that occurs due to optical system errors on the sensor and atmospheric interference. Masking aims to separate the land and water areas. If land and water are not separated, it will interfere with image interpretation in the next process. The separation of mangroves and non-mangroves is carried out with a supervised classification with the maximum likelihood approach. The selection of the supervised classification method with the maximum likelihood approach because this method can compare and calculate the average value of the diversity between the existing classes by performing parameter classification assuming a normal spectral distribution for each characteristic.

The calculation of the area of mangroves is done by using the processing results from the classification that has been done to separate between mangroves and non-mangroves. Then the mangrove area is calculated using mapping software. Mangrove density classification was carried out using the Normalized Difference Vegetation Index (NDVI) algorithm which aims to determine the density level of the mangrove canopy (Alatorre et al., 2016; Umroh et al., 2016; Valderrama-Landeros et al., 2018). The NDVI algorithm is based on the reflectance of a remote sensing object in the red and near-infrared spectrum channels. NDVI values have a range of values from -1 to 1 . The formula for the Normalized Difference Vegetation Index (NDVI) is:

$$
\mathrm{NDVI}=(\mathrm{NIR}-\mathrm{RED}) /(\mathrm{NIR}+\mathrm{RED})
$$

NDVI will generate a new image with a value range of -1 to +1 , if the value is getting closer to 1 the density is getting higher. The result of NDVI transformation classified into three density classes, namely sparse density, medium density and high density.

\subsubsection{Field data collection}

Data was collected by determining the station based on pre-survey data processing. In this study, 30 sample data were collected in the field which representing each class of mangrove density (sparse density, medium density and high density). The selection of 30 data sampling points was carried out based on pre-survey image data processing. Sample points are considered to represent the overall condition of the mangrove ecosystem in Segara Anakan, Cilacap.

Data was collected by measuring the diameter of the tree trunk at breast height (DBH) and taking four photos of the crown density in each of the observation plots. Diameter measurements are only carried out on stems with a diameter of $\geq 5 \mathrm{~cm}$ (Sitoe et al., 2014). Data was taken using a transect plot measuring 10 meters $\mathrm{x} 10$ meters at each sampling point.

\subsubsection{Post-survey data calculation}

At this stage, the processed image is combined with field survey data to calculate the Leaf Area Index (LAI), biomass, carbon sink, $\mathrm{CO} 2$ absorption, and accuracy assessment. LAI is the leaf area projected on a flat plane for each unit of land surface area covered by a tree canopy. LAI has a good correlation with NDVI (Green et al., 1997; Kamal et al., 2016). Measurement of the image LAI value is carried out by building a model between the NDVI value and the LAI value obtained in the field. The percentage value of mangrove cover is calculated based on photos taken from under the mangrove tree facing upwards. This analysis separates the pixels of the sky and the vegetation cover, so the percentage of the pixel number of mangrove cover can be calculated in the binary image analysis. Mangrove density calculation is done by calculating the number of trees obtained in the field. The status of mangrove damage is classified according to the Decree of the Minister of Environment No. 201 in 2004 (Table 1). 

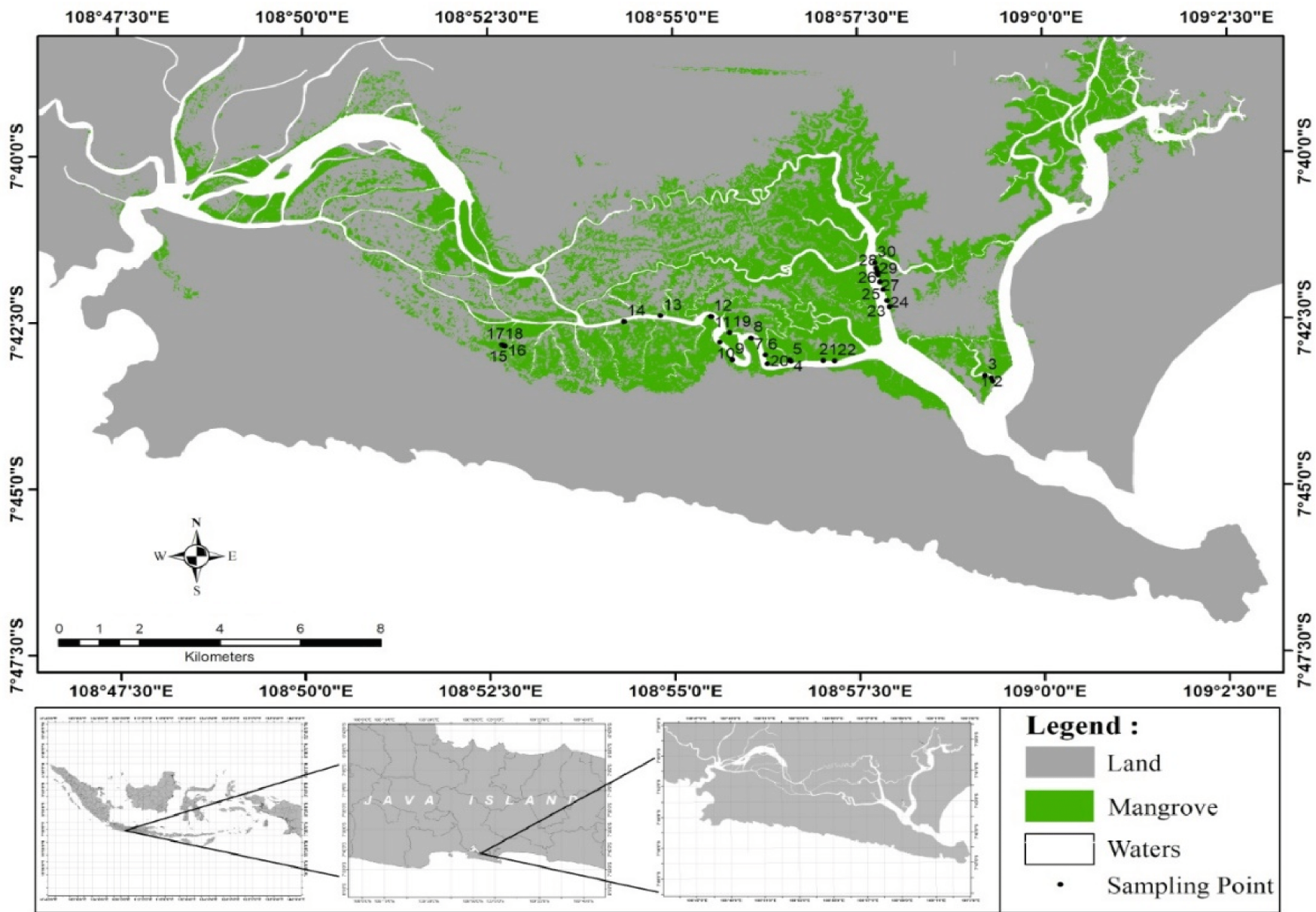

Figure 1. The mangrove area and location of the study site

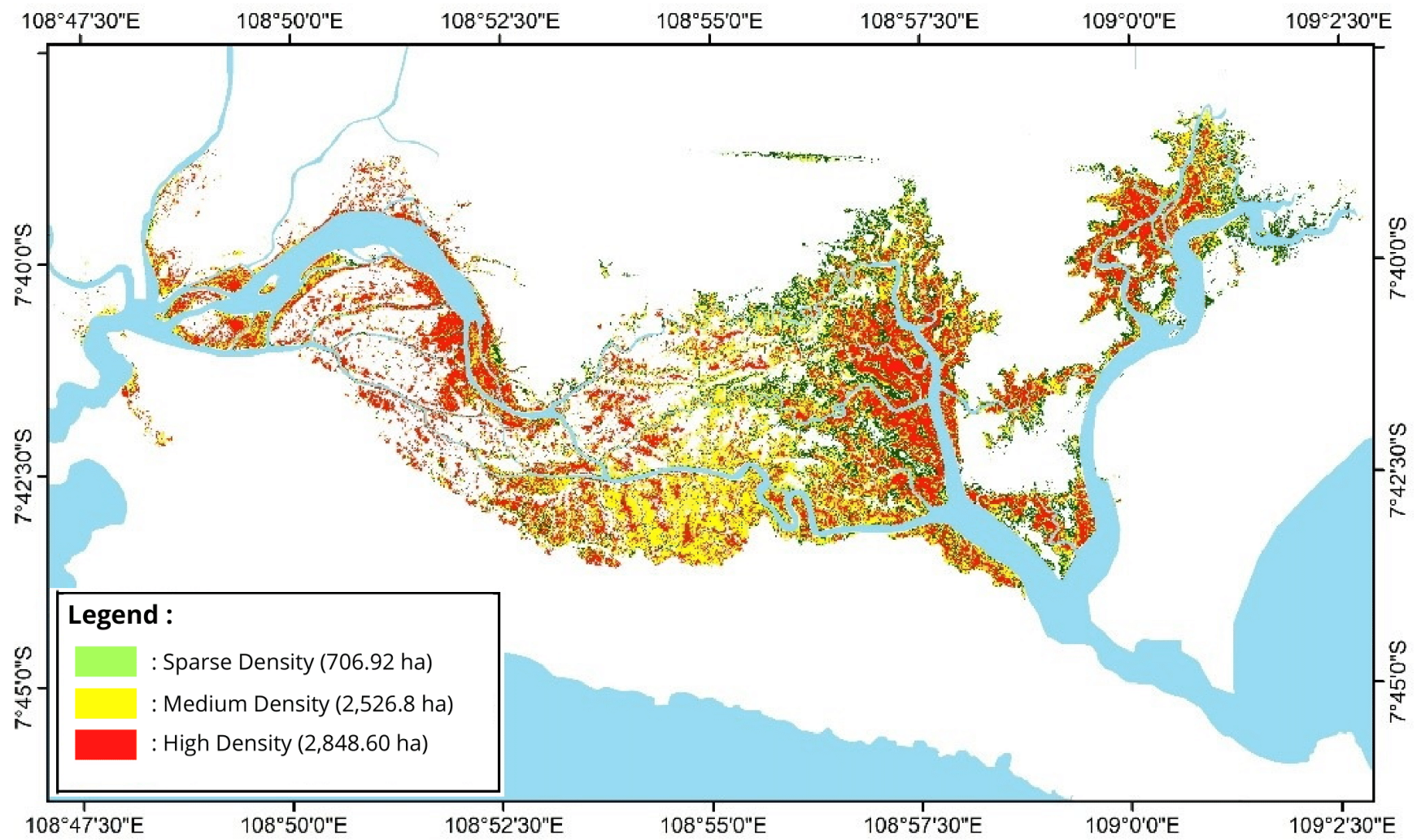

Figure 2. Density classification of mangrove forest in Segara Anakan

133 Jurnal Ilmiah Perikanan dan Kelautan 
JIPK. Volume 14 No 1. April 2022 / Carbon Sink Estimation of Mangrove Vegetation Using Remote Sensing in Segara.

Biomass content is defined as the total amount of living matter above the surface of a tree and expressed in units of dry weight per unit area (Siddiq et al., 2020). Calculation of the biomass of a tree can be done using an allometric approach (Table 2). In the study of forest biomass, tree allometric equations are used to determine the relationship between tree size (diameter or height) and overall tree weight. According to Siddiq et al. (2020) reported that mangrove forest biomass values are derived from allometric equations. The calculation of the biomass value based on the Sentinel 2A satellite image data is carried out by building a model using the LAI image value data with the biomass value obtained in the field. The model obtained was implemented using mapping software to obtain the overall biomass value.

The value of Carbon sink can be seen by tree biomass, $46 \%$ of biomass is carbon. So that the mangrove forest carbon sink can be calculated using Equation (2):

$$
\mathrm{C}=\mathrm{W} \times 0.46
$$

where $\mathrm{C}$ is Carbon sink (Mega gram/ha), and $\mathrm{W}$ is Biomass per mangrove species (Mega gram/ha). The value of $\mathrm{CO}_{2}$ absorption has different values for each species. The $\mathrm{CO}_{2}$ absorption value in a species can be calculated using Equation (3) (Brown, 1997; Utomo et al., 2021):

$$
\text { Absorption } \mathrm{CO}_{2}=\left(\frac{\mathrm{bmrCO}_{2}}{\mathrm{bmr} \mathrm{C}}\right) \times \text { Carbon sink }
$$

where bmr $\mathrm{CO}_{2}$ is relative molecular weight of $\mathrm{CO}_{2}=$ 44 , and bmr $\mathrm{C}$ is relative molecular weight $\mathrm{C}=12$.

The use of remote sensing for calculating the potential of mangroves as carbon sink is carried out using vegetation density analysis. The denser the vegetation, the greater the carbon content and vice versa. According to Frananda et al. (2015) rate of photosynthesis in denser vegetation areas is also higher, so rate of $\mathrm{CO}_{2}$ changes to biomass is faster in areas with denser vegetation. Computations for the ability of mangroves as carbon sink is carried out on each transects plot, Sentinel 2A satellite image has an accuracy of 10 meters $x$ 10 meters for each pixel. The size has been adjusted to the transect area used in each plots.

\subsection{Analysis Data}

The accuracy assessment was conducted to determine the density of mangroves by using NDVI and based on field data and to determine the deviation of LAI values from satellite imagery with data in the field. The accuracy test used is Confusion Matrix Table to see the deviation of the density value obtained in NDVI and in the field and RMSE (Root Mean Square Error) to see the deviation of the LAI value of the image and field data. The RMSE test is a test conducted to determine how much error occurs in the calculation results of the model when compared with the actual value. The smaller the RMSE value, the smaller errors that occur in using the model. RMSE calculation uses Equation (4).

$$
\operatorname{RMSE}=\frac{\Sigma\left(\mathrm{P}_{\mathrm{i}}-\mathrm{A}_{\mathrm{i}}\right)^{2}}{\mathrm{n}} \times 100 \%
$$

where $\mathrm{P}$ is the estimated value, $\mathrm{A}$ is the actual value, and $\mathrm{n}$ is number of validation observations.

Relationship between the value of carbon sink and the value of LAI was conducted using analysis regression. Regression analysis is used to measure how big the independent variable is able to explain the dependent variable, which is the independent variable is the LAI value and the dependent variable is the value of carbon sink in each sample. Linear regression analysis model simple method used in this study was done through the following equation:

$$
\mathrm{Y}=\mathrm{a}+\mathrm{bx}
$$

Description:

$\mathrm{Y}=$ dependent variable

$\mathrm{a}=$ regression coefficient (value of $\mathrm{y}$ if $\mathrm{x}=0$ )

$\mathrm{b}=$ regression coefficient

$\mathrm{x}=$ independent variable

\section{Results and Discussion}

\subsection{Results}

\subsubsection{Mangrove area and density in Segara Anakan}

Calculation of the area of mangrove forests in Segara Anakan Cilacap in 2019 obtained a total area of 5481.64 ha (Figure 1). The types of mangroves found, namely Avicennia marina (Forssk.), Rhizophora mucronate (Lam), Rhizophora apiculate (Blume), Ceriops tagal (Perr. C.B. Rob), Aegiceras corniculatum (Blanco), Sonneratia alba (J. Smith), and Bruguiera gymnorrhiza (L. Savigny). Data processing using Sentinel-2A satellite imagery shows that the density using NDVI has a pixel value range between $0.48-0.84$. These values are classified into three categories, namely the sparse category $(0,48-0.60)$, medium $(0.61-0.73)$, and high $(0.48$ 0.60 ). Based on this classification, mangroves with high density were obtained with an area of 2,848.60 ha, medium density of 2526.80 ha, and sparse density of 706.92 ha (Figure 2). 
Aulia et al. / JIPK, 14(1): 130-141

Table 1. The standard for mangrove forest damage

\begin{tabular}{rlll}
\hline \multicolumn{1}{c}{ Criteria } & Density & Cover Area (\%) & Density (Tree/ha) \\
\hline \multirow{2}{*}{ Good } & High & $\geq 75 \%$ & $\geq 1500$ \\
& Medium & $50 \%-75 \%$ & $1000-1500$ \\
\multirow{2}{*}{ Damaged } & Sparse & $<50 \%$ & $<1000$ \\
\hline
\end{tabular}

Source: Decree of the Indonesian Minister of Environment No. 201 in 2004

Table 2. The standard for mangrove forest damage

\begin{tabular}{llll}
\hline Mangrove Species & \multicolumn{2}{l}{ Diameter $\mathbf{( c m )}$ Allometric Approaching } & Sources \\
\hline Avicennia marina & $5-35$ & $\mathrm{~W}=0.308 \times(\mathrm{DBH})^{2.11}$ & (Comley and McGuinness, 2005) \\
Aegiceras corniculatum & $5-35$ & $\mathrm{~W}=0.2064 \times(\mathrm{DBH})^{2.34}$ & (Siregar and Dharmawan, 2009) \\
Bruguiera gymnorrhiza & $5-48.9$ & $\mathrm{~W}=0.251 \times 0.699(\mathrm{DBH})^{2.46}$ & (Fatoyinbo et al., 2008) \\
Ceriops tagal & $5-48.9$ & $\mathrm{~W}=0.251 \times 0.746(\mathrm{DBH})^{2.46}$ & (Fatoyinbo et al., 2008) \\
Rhizophora mucronata & $5-48.9$ & $\mathrm{~W}=0.251 \times 0.701(\mathrm{DBH})^{2.46}$ & (Fatoyinbo et al., 2008) \\
Rhizopora apiculata & $5-28$ & $\mathrm{~W}=0.235 \times(\mathrm{DBH})^{2.42}$ & (Ong et al., 2004) \\
Sonneratia alba & $5-48.9$ & $\mathrm{~W}=0.251 \times 0.475(\mathrm{DBH})^{2.46}$ & (Fatoyinbo et al., 2008) \\
Xylocarpus granatum & $5-25$ & $\mathrm{~W}=0.251 \times 0.528(\mathrm{DBH})^{2.46}$ & (Fatoyinbo et al., 2008) \\
\hline
\end{tabular}

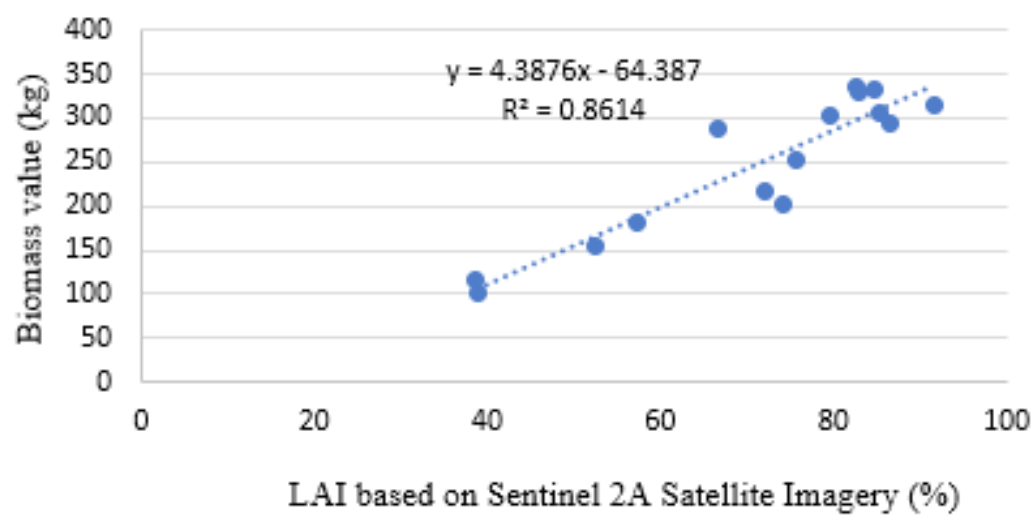

Figure 3. Relationship between LAI value of Sentinel-2A image and field biomass

The ability of NDVI to map mangrove density was tested using linear regression. The results of the linear regression model produced by the NDVI index on the percentage value of canopy density in the field are $\mathrm{Y}=$ $0.003 x+0.5168$ with an $R^{2}$ value of 0.85 and $r$ of 0.92 . These results indicate that there is a positive relationship which indicates a strong relationship, which means that the greater the NDVI value, the greater the percentage value of mangrove canopy density. Mapping of mangrove density using Sentinel-2A satellite imagery using the NDVI algorithm produces an accuracy of $86.92 \%$.

\subsubsection{Potential of mangrove forest as carbon sink}

LAI values based on field measurements are calculated by analyzing photos using ImageJ software, while the LAI image is calculated by modelling a formula built from the equation for the vegetation index value (Table 3). The relationship between LAI of measurements and LAI of images is determined using linear regression methods. Meanwhile, the accuracy between LAI of measurements and LAI of image is calculated by RMSE-value. The results of the linear regression model for LAI of measurements against the LAI of image are $Y=0.7799 x+13.684$ with $R^{2}$ value of 0.83 and $r$ of 0.91 . This result means that there is a positive strong relationship, which means that the greater the LAI of measurements, the greater the LAI of image. The RMSE value obtained from the LAI of measurements and LAI of image is 0.01 , this means that the data has an accurate value. 
Table 3. Comparison of LAI values and biomass

\begin{tabular}{lllll}
\hline $\begin{array}{l}\text { Number } \\
\text { Station }\end{array}$ & $\begin{array}{l}\text { LAI of } \\
\text { Measurements (\%) }\end{array}$ & $\begin{array}{l}\text { LAI of } \\
\text { Image }(\%)\end{array}$ & $\begin{array}{l}\text { Biomassa based } \\
\text { on Field Data (kg) }\end{array}$ & $\begin{array}{l}\text { Biomassa } \\
\text { based Imagery (kg) }\end{array}$ \\
\hline 1 & 93.74 & 83.03 & 328.77 & 284.95 \\
2 & 63.34 & 74.14 & 202.13 & 250.52 \\
3 & 89.71 & 66.74 & 287.02 & 221.85 \\
4 & 33.1 & 38.96 & 101.42 & 114.24 \\
5 & 36.68 & 38.66 & 115,69 & 126.87 \\
6 & 54.27 & 57.34 & 181.91 & 185.44 \\
7 & 57.64 & 52.35 & 154.04 & 166,13 \\
8 & 80.97 & 71.94 & 217.29 & 241.93 \\
9 & 77.64 & 75.68 & 252.75 & 256.47 \\
10 & 84.31 & 91.56 & 315.69 & 317.96 \\
11 & 87.08 & 82.7 & 335.29 & 283.63 \\
12 & 88,13 & 84.65 & 331.6 & 291.91 \\
13 & 81.02 & 79.65 & 302.55 & 261.95 \\
14 & 89.27 & 85.28 & 304.81 & 293.66 \\
15 & 90.74 & 86.39 & 293.81 & 266.78 \\
\hline
\end{tabular}

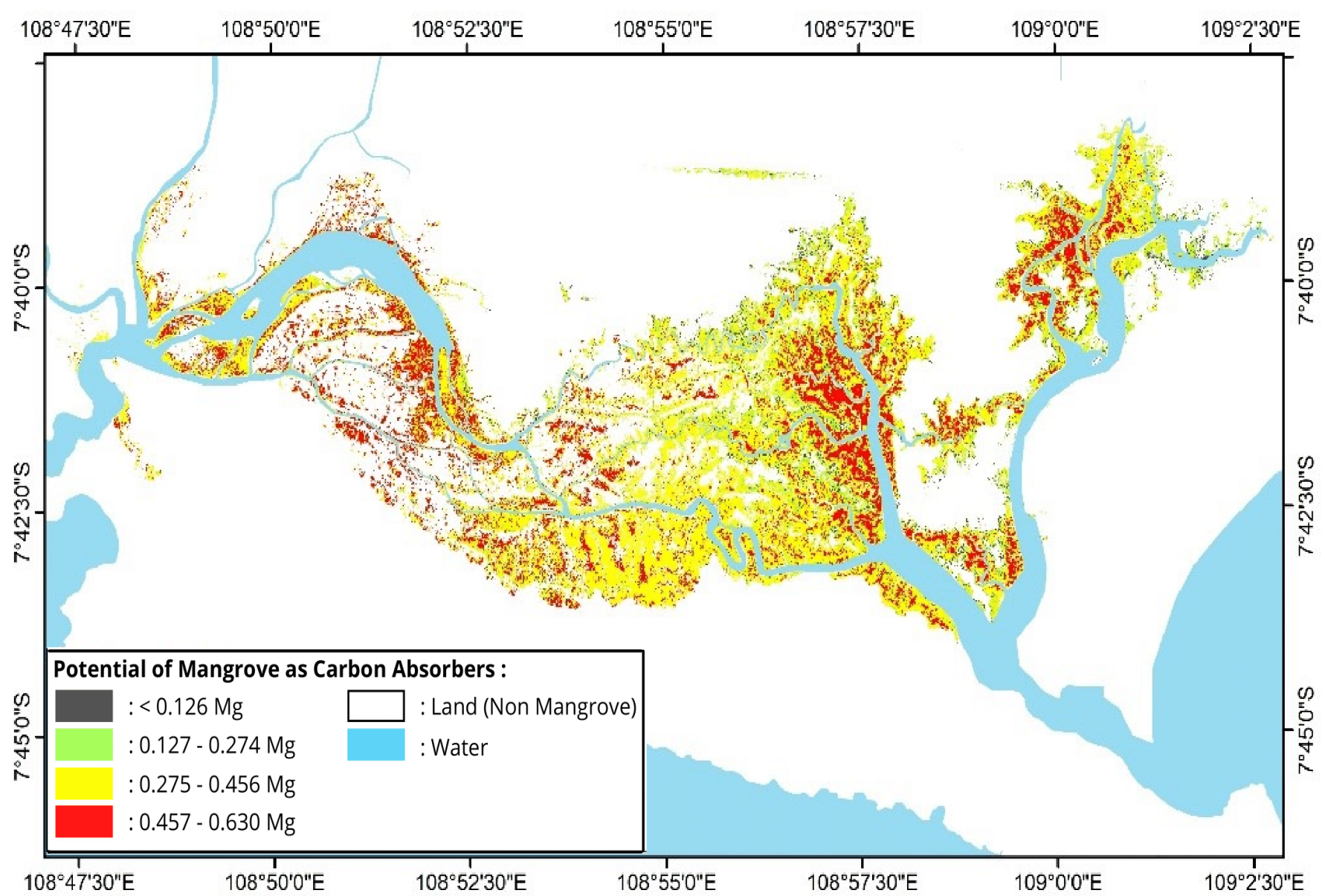

Figure 4. Potential of mangroves as carbon absorbers 
Leaf Area Index is defined as the projected leaf area per unit of land area. According to this study, there is a strong relationship between LAI and NDVI. Measurement of LAI in the field is carried out to determine the biomass content of a tree, this is due to the relationship between leaf biomass and mangrove tree biomass. The value of mangrove leaf biomass can be estimated from wood density and stem diameter (Komiyama et al., 2005; Sani and Hashim, 2018). Thus, leaf biomass has a strong correlation with biomass of branches, stems, or roots. Therefore, LAI also has a strong correlation with tree biomass and carbon stock because LAI is a part of leaf biomass. So, the results of measuring the LAI value can be used to calculate the estimated carbon stock in a mangrove tree.

The measurement of carbon stocks was estimated using a conversion rate, which is $46 \%$ of the total biomass values. The calculation of the biomass value is done by measuring the stem diameter in the field. Then the stem diameter data obtained, the biomass value is calculated using the allometric equation. Meanwhile, the calculation of biomass using Sentinel-2A imagery is done by modelling a formula that is built from the equation between the LAI value obtained from the Sentinel-2A image and the biomass value obtained in the field (Figure 3). The resulting linear regression model are $\mathrm{Y}=4.3876 \mathrm{x}-64,387$ with $\mathrm{R}^{2}$ value of 0.86 and $\mathrm{r}$ of 0.93 . The results of this correlation indicate a positive relationship which indicates a strong relationship, which means that the greater the LAI value, the greater the value of mangrove biomass. So the regression is used to find the total biomass value of mangrove forests in Segara Anakan, Cilacap using Sentinel-2A imagery (Table 3).

The comparison between biomass values was measured directly in the field with the biomass value obtained from the Sentinel-2A image (Table 3). To determine the accuracy between the two data, a linear regression analysis was carried out. From the analysis results obtained $\mathrm{R}^{2}$ value of 0.86 and $\mathrm{r}$ of 0.93 . These results indicate a positive relationship which states that there is a strong relationship between the biomass value obtained using Sentinel-2A image and the biomass value obtained from direct measurements in the field, which means that the greater the biomass value obtained using Sentinel-2A image, the greater also the biomass value obtained from direct measurements in the field. This study shows the total biomass value of the mangrove forests in Segara Anakan was 30,644,772.80 kg or 27,800.47 Mega gram. The mangrove biomass value obtained was then used to calculate the value of the car- bon content in mangroves. Calculation of the value of carbon stock was carried out by multiplying the value of biomass by 0.46 so that the value of the mangrove forest carbon stock in Segara Anakan, Cilacap was 12,788.22 Mega gram or $2.33 \mathrm{Mg} / \mathrm{ha}$.

Calculation of the ability of mangrove forests to absorb carbon is done by multiplying the value of carbon stocks by 3.76 . The value of 3.76 is obtained from the result of dividing the value of the relative molecular weight of $\mathrm{CO}_{2}$ (44) with the value of the relative molecular weight of C (12). So the value of the ability of mangrove forests in Segara Anakan, Cilacap as a carbon sink is $8.56 \mathrm{Mg} / \mathrm{ha}$ (Figure 4).

\subsection{Discussion}

Mangrove forest in Segara Anakan, Cilacap is the largest mangrove forest on Java Island. It is known that mangroves in Segara Anakan, Cilacap live and grow along the river lines (Figure 1). This is because the ecosystem of mangrove is an ecosystem in the intertidal zone, between land and sea. So, mangroves need a supply of salt water and fresh water to survive. This is supported by research conducted by Kusmana and Sukristijiono (2016) that mangrove forests have their uniqueness and uniqueness due to their unstable and muddy habitat, freshwater overflow from rivers and incoming seawater flows are the main factors affecting growth and development. The intertidal zone is characterized by a wide variety of environmental factors, such as temperature, salinity, sedimentation, and tidal currents.

Mangrove can grow optimally in coastal environments that have large river estuaries and deltas where the water flow contains a lot of mud. Mangrove plants are often found in coastal areas that are protected from the onslaught of waves. This is following the opinion of Kusmana and Sukristijiono (2016) that waves can change the structure and function of mangroves. In a location that has quite high waves and currents, it will usually experience abrasion resulting in a reduction in mangrove area. Segara Anakan, Cilacap is an area that has waves and currents that are low enough so mangroves can thrive in this location.

The area of mangrove forest in Segara Anakan continues to decline every year. In 1997, the area of the Segara Anakan mangrove forest was 13,557 ha, reduced in 2004 to 9,272 ha (Ardli, 2008), in 2012 it was 8,037 ha (Listyaningsih et al., 2013) until 2016 it was 6128 ha (Ismail et al., 2018). The continuous reduction in mangrove forest area is caused by several aspects, one of 
which is an increase in development activities that have turned mangrove forests into settlements, industries, rice fields, and ponds. The main factors that cause a decrease in mangrove forest area are the conversion of mangrove land to another land, illegal logging, and pollution. Anthropogenic factors are also important factors that can cause damage to mangrove forest ecosystems and can cause a decrease in biodiversity in mangrove forests. Industrial activities are also one of the factors that cause a decrease in the area of mangrove forests. That chemical, industrial, and urban waste can hurt mangrove plants so that mangroves cannot grow properly (Celis-Hernandez et al., 2020).

Mangrove density in eastern Segara Anakan tends to have a high density compared to other locations. This is because the area has suitable environmental conditions to support mangrove growth which is reinforced by research conducted by (Hilmi et al., 2015) that the eastern Segara Anakan area has a salinity range of 4.47$17 \mathrm{ppt}$, water $\mathrm{pH}$ 7, DO ranges from $3-5.4 \mathrm{mg} / \mathrm{l}$ and the altitude of the site is $5-20$ masl. This condition is a suitable condition for mangrove growth, mangroves usually thrive in estuary areas with salinity levels between 10-30 ppt. Besides, the mangrove forest in the eastern part of Segara Anakan is a pure mangrove forest where there are no human settlements so that it is under lower anthropogenic pressure.

Central and western mangrove forests in Segara Anakan tend to have sparse and medium density. This is because mangrove forests in the central and western get enormous pressure from sedimentation, land conversion, and anthropogenic factors. The middle part of the Segara Anakan area is a densely populated area so there are many anthropogenic influences at this location that disrupt mangrove growth.

Mapping of mangrove density using Sentinel-2A satellite imagery using the NDVI algorithm produces an accuracy of $86.92 \%$. The results of the accuracy assessment sufficient standard value of accuracy assessment because it has a value of $\geq 70 \%$. Based on research conducted by (Pratama et al., 2019) using NDVI to map mangrove density using Sentinel-2A satellite imagery can produce an accuracy of $86.07 \%$.

Carbon stock measurement mangrove forest in Segara Anakan, Cilacap results obtained 12,788.22 Mega gram or $2.33 \mathrm{Mg} / \mathrm{ha}$. The value of biomass is influenced by the value of tree diameter. The larger the tree diameter, the greater the tree biomass (Windarni et al., 2018). The amount of forest biomass is also determined by diameter, height, wood density, density, and soil fer- tility. While, the value of the ability of mangrove forests in Segara Anakan, Cilacap as a carbon sink is $8.56 \mathrm{Mg} /$ ha. The ability of mangroves to store carbon has been carried out in several areas in the tropics. Mangrove forest in Nusa Lembongan Bali have total carbon stock $20.92 \mathrm{Mg} / \mathrm{ha}$ (Pricillia et al., 2021). According to (Wicaksono et al., 2016) there are approximately 120,546 tonnes carbon of mangrove biomass carbon stock in the Karimunjawa Islands with Above Ground Carbon mean value of $21.64 \mathrm{~kg} / \mathrm{m}^{2}$. Mangrove forest in Youteva Bay, Jayapura, Papua have ability to absorb 6.91 tonnes carbon/hectare (Ramba et al., 2021). In Bama Resort, Baluran National Park Indonesia, mangrove have ability to absorb $239.8 \pm 256.9 \mathrm{Mg}$ carbon/hectare (Asadi and Pambudi, 2020).

Each mangrove pixel and species can absorb different carbon. The ability of mangrove forests to absorb carbon is influenced by several factors, one of which is the size of the tree trunk. This is following the research conducted by (Windarni et al., 2018) that increasing the diameter of the tree trunk shows the more $\mathrm{CO}_{2}$ absorbed by the tree. Plants can absorb $\mathrm{CO}_{2}$ from the air and convert it into organic compounds through the process of photosynthesis. According to Nuraini et al., (2021) mangrove forest have the ability to absorb carbon, some of the carbon will be used as energy for plant physiology and some will enter the plant structure and become part of the plant, for example cellulose which is stored in stems, roots, twigs, and leaves.

The ability of mangrove as carbon sink provides great benefits for the fisheries and marine organism. According to Nehren and Wicaksono (2018) mangrove forest have the ability to absorb $\mathrm{CO}_{2}$ which is then used to photosynthesis which will produce energy. The energy will be utilized by marine organisms that live in the mangrove forest area. The blue carbon sink potential of mangroves helps to offset carbon emissions that can endanger the survival of marine organism.

\section{Conclusion}

Mangrove forest in Segara Anakan, Cilacap has an area of 5481.64 ha of which area of sparse density was $706.92 \mathrm{ha}$, medium density has an area of 2526.8 ha, and high density has an area of 2848.6 ha. The accuracy for mangrove density was $86.92 \%$ with r-value 0.85. Mangrove in Segara Anakan has the ability to absorb 8.56 Mega gram $(\mathrm{Mg})$ of carbon per hectare.

\section{Acknowledgement}

Thank you to the Centre for Maritime Biosci- 
ence, Institute for Research and Community Services Jenderal Soedirman University for providing the opportunity to fund this research.

\section{Authors' Contributions}

Each author participated in the research process and final manuscript with discussion of the results and contributed to revising the final manuscript.

\section{Conflict of Interest}

The authors state that they have no competing interests including of competing financial interest or the other competing interest.

\section{Funding Information}

This research was supported by Universitas Jenderal Soedirman and Centre for Maritime Bioscience, Institute for Research and Community Services Jenderal Soedirman University for providing the opportunity to fund this research.

\section{References}

Alatorre, L. C., Sánchez-Carrillo, S., Miramontes-Beltrán, S., Medina, R. J., Torres-Olave, M. E., Bravo, L. C., Wiebe, L. C., Granados, A., Adams, D. K., Sánchez, E., \& Uc, M. (2016). Temporal changes of NDVI for qualitative environmental assessment of mangroves: Shrimp farming impact on the health decline of the arid mangroves in the Gulf of California (1990-2010). Journal of Arid Environments, 125:98-109.

Ardli, E. R. (2008). A trophic flow model of the Segara Anakan Lagoon, Cilacap, Indonesia. Dissertation. Bremen: University of Bremen.

Asadi, M. A., \& Pambudi, G. S. (2020). Diversity and biomass of mangrove forest within Baluran $\mathrm{Na}-$ tional Park, Indonesia. AACL Bioflux, 13(1):1927.

Askar, Nuthammachot, N., Phairuang, W., Wicaksono, P., \& Sayektiningsih, T. (2018). Estimating aboveground biomass on private forest using sentinel-2 imagery. Journal of Sensors, 2018:1-11.

Bindu, G., Rajan, P., Jishnu, E. S., \& Ajith Joseph, K. (2020). Carbon stock assessment of mangroves using remote sensing and geographic information system. Egyptian Journal of Remote Sensing and Space Science, 23(1):1-9.
Brown, R. A., \& Rosenberg, N. J. (1997). Sensitivity of crop yield and water use to change in a range of climatic factors and $\mathrm{CO} 2$ concentrations: a simulation study applying EPIC to the central USA. Agricultural and Forest Meteorology, 83(3-4):171-203.

Celis-Hernandez, O., Giron-Garcia, M. P., Ontiveros-Cuadras, J. F., Canales-Delgadillo, J. C., Pérez-Ceballos, R. Y., Ward, R. D., Acevedo-Gonzales, O., Armstrong-Altrin, J. S., \& Merino-Ibarra, M. (2020). Environmental risk of trace elements in mangrove ecosystems: An assessment of natural vs oil and urban inputs. Science of the Total Environment, 730:138643.

Comley, B. W. T., \& McGuinness, K. A. (2005). Aboveand below-ground biomass, and allometry, of four common northern Australian mangroves. Australian Journal of Botany, 53(5):431-436.

Donato, D. C., Kauffman, J. B., Murdiyarso, D., Kurnianto, S., Stidham, M., \& Kanninen, M. (2011). Mangroves among the most carbon-rich forests in the tropics. Nature Geoscience, 4(5):293297.

Fatoyinbo, T. E., Simard, M., Washington-Allen, R. A., \& Shugart, H. H. (2008). Landscape-scale extent, height, biomass, and carbon estimation of Mozambique's mangrove, forests with Landsat ETM+ and Shuttle Radar Topography Mission elevation data. Journal of Geophysical Research: Biogeosciences, 113(2):1-13.

Frananda, H., Hartono, \& Jatmiko, R. H., (2015). Komparasi indeks vegetasi untuk estimasi stok karbon hutan mangrove kawasan Segoro Anak pada kawasan Taman Nasional Alas Purwo Banyuwangi, Jawa Timur (Comparison of vegetation indices for mangrove carbon stock estimation in Segoro Anak Area, Alas Purwo National Park, Banyuwangi, East Java). Majalah Ilmiah Globë, 17(2):113-123.

Green, E. P., Mumby, P. J., Edwards, A. J., Clark, C. D., \& Ellis, A. C. (1997). Estimating leaf area index of mangroves from satellite data. Aquatic Botany, 58(1):11-19.

Hilmi, E., Siregar, A. S., \& Febryanni, L. (2015). Struktur komunitas, zonasi dan keanekaragaman hayati vegetasi mangrove di Segara Anakan Cilacap. Omni-Akuatika, 11(2):20-32.

Ismail, Sulistiono, Hariyadi, S., \& Madduppa, H. 
(2018). Condition and mangrove density in Segara Anakan, Cilacap Regency, Central Java Province, Indonesia. AACL Bioflux, 11(4):10551068.

Kamal, M., Phinn, S., \& Johansen, K. (2016). Assessment of multi-resolution image data for mangrove leaf area index mapping. Remote Sensing of Environment, 176:242-254.

Komiyama, A., Poungparn, S., \& Kato, S. (2005). Common allometric equations for estimating the tree weight of mangroves. Journal of Tropical Ecology, 21(4):471-477.

Kusmana, C., \& Sukristijiono, S. (2016). Mangrove resource uses by local community in Indonesia. Journal of Natural Resources and Environmental Management, 6(2):217-224.

Listyaningsih, D. D., Yulianda, F., \& Ardli, E. R. (2013). Assessment of mangrove ecosystem degradation to the population of Polymesoda erosa in Segara Anakan, Cilacap. Forum Geografi, 27(1):1-10.

Muhsoni, F. F., Sambah, A. B., Mahmudi, M., \& Wiadnya, D. G. R. (2018). Estimation of mangrove carbon stock with hybrid method using image Sentinel-2. International Journal of Geomate, 15(49):185-192.

Murdiyarso, D., Purbopuspito, J., Kauffman, J. B., Warren, M. W., Sasmito, S. D., Donato, D. C., Manuri, S., Krisnawati, H., Taberima, S., \& Kurnianto, S. (2015). The potential of Indonesian mangrove forests for global climate change mitigation. Nature Climate Change, 5(12):1089-1092.

Nehren, U., \& Wicaksono, P. (2018). Mapping soil carbon stocks in an oceanic mangrove ecosystem in Karimunjawa Islands, Indonesia. Estuarine, Coastal and Shelf Science, 214:185-193.

Nguyen, H. H., Quang, P. D., Nguyen, V. D., Linh, T. V. K., Duong, L. V. K., \& Manh, N. K. (2020). Management of forest resources and environment estimation of mangrrove carbon stocks using Sentinel 2A and Field-Based Data in Tien Lang District, Hai Phong City. Journal of Forestry Science and Technology, (10):48-58.

Nuraini, R. A. T., Pringgenies, D., Suryono, C. A., \& Adhari, V. H. (2021). Stok karbon pada tegakan vegetasi mangrove di Pulau Karimunjawa.
Buletin Oseanografi Marina, 10(2):180-188.

Ong, J. E., Gong, W. K., \& Wong, C. H. (2004). Allometry and partitioning of the mangrove, Rhizophora apiculata. Forest Ecology and Management, 188(1-3):395-408.

Parida, B. R., \& Kumari, A. (2020). Mapping and modeling mangrove biophysical and biochemical parameters using Sentinel-2A satellite data in Bhitarkanika National Park, Odisha. Modeling Earth Systems and Environment, 7:2463-2474.

Patil, V., Singh, A., Naik, N., \& Unnikrishnan, S. (2015). Estimation of mangrove carbon stocks by applying remote sensing and GIS techniques. Wetlands, 35(4):695-707.

Pratama, I. G. M. Y., Karang, I. W. G. A., \& Suteja, Y. (2019). Distribusi spasial kerapatan mangrove menggunakan citra Sentinel-2A di Tahura Ngurah Rai Bali. Journal of Marine and Aquatic Sciences, 5(2):192-202.

Pricillia, C. C., Patria, M. P., \& Herdiansyah, H. (2021). Environmental conditions to support blue carbon storage in mangrove forest: A case study in the mangrove forest, Nusa Lembongan, Bali, Indonesia. Biodiversitas, 22(6):3304-3314.

Ramba, F. Y., Wirasatriya, A., \& Yulianto, B. (2021). Recent update of mangrove carbon-stock estimation using vegetation index analysis at Youtefa Bay, Jayapura, Papua, Indonesia. Ecology, Environment \& Conservation, 27:S57-S65.

Sani, D. A., \& Hashim, M. (2018). A preliminary work on blue carbon stock mapping in mangrove habitat using satellite-based approach. IOP Conference Series: Earth and Environmental Science, 169(1):012078.

Siddiq, A., Dimyati, M., \& Damayanti, A. (2020). Analysis of carbon stock distribution of mangrove forests in the coastal city of Benoa, Bali with combination vegetation index, and statistics approach. International Journal on Advanced Science Engineering Information Technology, 10(6):2386-2393.

Siregar, C. A., \& Dharmawan, I. W. S. (2009). Biomassa karbon pada hutan tanaman mangrove: Laporan Hasil Penelitian. Bogor: Pusat Penelitian Hutan dan Konservasi Alam.

Sitoe, A. A., Mandlate, L. J. C., \& Guedes, B. S. (2014). Biomass and carbon stocks of Sofala Bay man- 
grove forests. Forests, 5(8):1967-1981.

Umroh, Adi, W., \& Sari, S. P. (2016). Detection of mangrove distribution in Pongok Island. Procedia Environmental Sciences, 33:253-257.

Utami, F. P., Prasetyo, Y., \& Sukmono, A. (2016). Analisis spasial perubahan luasan mangrove akibat pengaruh limpasan sedimentasi tersuspensi dengan metode penginderaan jauh. Jurnal Geodesi Undip, 5(1):305-315.

Utomo, S. W., Pambudi, P. A., Pramudianto, A., \& Sudaryanto. (2021). The carbon dioxide (CO2) sequestration potential of conservation plant Aquilaria malaccensis. IOP Conference Series: Earth and Environmental Science, 724(1).

Vafaei, S., Soosani, J., Adeli, K., Fadaei, H., Naghavi, H., Pham, T. D., \& Bui, D. T. (2018). Improving accuracy estimation of forest aboveground biomass based on incorporation of ALOS-2 PALSAR-2 and Sentinel-2A imagery and machine learning: A case study of the Hyrcanian forest area (Iran). Remote Sensing, 10(2):172.
Valderrama-Landeros, L., Flores-de-Santiago, F., Kovacs, J. M., \& Flores-Verdugo, F. (2018). An assessment of commonly employed satellite-based remote sensors for mapping mangrove species in Mexico using an NDVI-based classification scheme. Environmental Monitoring and Assessment, 190(23):1-13.

Wang, D., Wan, B., Qiu, P., Su, Y., Guo, Q., Wang, R., Sun, F., \& Wu, X. (2018). Evaluating the performance of Sentinel-2, Landsat 8 and Pléiades-1 in mapping mangrove extent and species. Remote Sensing, 10(9):1468.

Wicaksono, P., Danoedoro, P., Hartono, \& Nehren, U. (2016). Mangrove biomass carbon stock mapping of the Karimunjawa Islands using multispectral remote sensing. International Journal of Remote Sensing, 37(1):26-52.

Windarni, C., Setiawan, A., \& Rusita, R. (2018). Carbon stock estimation of mangrove forest in Village Margasari Sub-District Labuhan Maringgai District East Lampung. Jurnal Sylva Lestari, 6(1):66-74. 